\title{
Enzymatic Liquefaction of Cell-Walls from Kent and Tommy Atkins Mango Fruits
}

\author{
Beatriz Brito ${ }^{1}$, Fabrice Vaillant ${ }^{2, *}$ \\ ${ }^{1}$ Instituto Nacional Autónomo de Investigaciones A gropecuarias (INIAP), Departamento de Nutrición y Calidad, A.P. 340, Quito, Ecuador \\ ${ }^{2}$ Centre de Coopération Internationale en Recherche Agronomique pour le Développement (CIRAD), Tropical Fruits Department \\ (FLHOR), B.P. 5085, 34032 Montpellier Cedex 1, France
}

\begin{abstract}
Table mango varieties discarded by the export market are generally not considered suitable for processing mainly because they yield too viscous fruit purées. The objective of this study was determining if appropriate enzy matic treatment can overcome this barrier. Cell-wall polysaccharides from mesocarp and pericarp of fully ripe table mangoes were characterized analy zing the alcohol-insoluble residues (AIR). Content of celluloses, hemicellu loses, lignin and soluble and insoluble pectin were assessed after selective extraction. After hydrolysis of main fractions, neutral sugars were determined by gas chromatography showing that xylose prevails (12-14\%) in the non-cellulosic fraction of insoluble cell walls from mesocarp, indicating predominance with cellulose, of xilan-type polysaccharides in mango flesh. Water insoluble AIR (WAIR) was incubated with commercial preparations, characterized for their main enzy matic activities and comprising balanced proportion of pectinases and cellulases with other different secondary activities. At equivalent $500 \mu 1$ per kilogram of purée and at $45^{\circ} \mathrm{C}$, solubilisation rates of uronids and neutral sugars reach respectively 100 and $90 \%$ only when xy lanase activities were present. Then, a commercial enzy me preparation containing pectinases, cellulases and high xylanase activities was applied to native mango purée varying enzyme concentration and incubation time according to a central composite rotatable design. It was shown that percent of final suspended insoluble solids and Bostwick consistency could be considerably reduced in minutes, using a relatively low a mount of enzyme preparation $\left(150 \mu 1 . \mathrm{L}^{-1}\right)$. Rheological properties of mango purées can be modulated easily according to incubation time and concentration of enzymatic solution to fit the needs of food industries.
\end{abstract}

Keywords Mango, Cell-Wall Polysaccharides, Enzy mes, Bostwick Consistency

\section{Introduction}

Global production of mango was forecasted to reach alm ost 32 million tonnes by 2010 , fro $m$ wh ich appro ximately 1,5 million were exported worldwide as fresh fruit[1]. Exported fresh fruits correspond to varieties that were selected for their firmness even at optimal maturity, as they must undergo considerable handling from field to international market, sometimes including hot-water treatments to reduce anthracnose incidence or eradicate fruit flies as required by the US market[2]. The varieties that can meet these technological requirements can be called table varieties, with Tommy Atkins and Kent among the main traded varieties.

The high standards of quality imply that large quantities of fruit must be discarded by packing houses for being misshapen or having visual defects. Even in well managed plantations in Ecuador for instance, $20 \%$ to $30 \%$ of fruits are

* Corresponding author:

fabrice.vaillant@cirad.fr (Fabrice Vaillant)

Published online at http://journal.sapub.org/food

Copyright (C) 2012 Scientific \& Academic Publishing. All Rights Reserved discarded in the fields and packing houses. These fruits are usually sold at low prices in local markets or even dumped in some cases. Although these mangoes have good internal properties, they are scarcely used by the juice industry because of poor technological properties such as low juice yield and highly viscous purée. Actually, other varieties are much more appropriate for juice production such as the Indian varieties Alphonso and Totapuri, which represent most of the international trade in mango purée[3, 4]. These varieties give off better aro ma, have a higher ju ice yield and lower content of suspended insoluble solids than table mango varieties. Even so, the low value of the significant amount of discarded table mangos has become a major constraint to increasing the competitiveness of the export mango agro-industry. Special effort must therefore be made to process this fruit into a valuable product.

Renewed interest in fruit products rich in dietary fibbers may also represent an opportunity for adding value to products prepared with table mangos $[5,6]$. In fact, their technological characteristics, high viscosity and consistency, and low juice yield can be improved by using appropriate enzymes to degrade cell-wall polysaccharides, which are 
responsible for the purée's rheological properties. Characterization of cell-wall polysaccharides has been studied by some authors for Alphonso[7, 8], Tommy Atkins and other varieties [8-11], but emphasis was put on studying ripening and natural tissue softening of mango fruit. Although studies on enzymatic liquefaction of viscous fruit juice to achieve better concentration rates are yet to be generally performed, all of them have been carried out on mango varieties appropriate for juice extraction and not on table mangoes [3, 12-15] except for Keitt variety[16]. Even these studies have been limited to testing commercial preparation, and little information is availab le on the relevant enzymatic activities that should be involved to reach the targeted technologicale ffect. Consequently, for the two ma in table varieties (Tommy Atkins and Kent), specific studies are likewise necessary.

This paper deals with (1) the characterization of cell-wall fruit polysaccharides of fully mature fruit, (2) the subsequent selection of an appropriate enzymatic preparation that can better liquefy cell-walls polysaccharides, and (3) application to purées to obtain different Bostwick consistencies and extend the industrial uses of discarded fruits. Actually, Bostwick consistency index is of very high practical interest for many industrial processes, in various fruit industries [17].

\section{Materials and Methods}

\subsection{Raw Materials}

Green mangos were randomly selected from five packing houses. They were physiologically mature, but discarded by the export market for physical defects. All fruits were harvested from commercial plantations located in the Province of Guayas (Ecuador). Fruits were ripened at $22^{\circ} \mathrm{C}$ and $\mathrm{RH} 75 \%$ for at least 8 days, and only coloured fruits (i.e. with more than $60 \%$ of the surface red for the variety To mmy Atkins and yellow for Kent) were selected.

Fruits were manually peeled and mesocarp was separated and pulped with a processor, and then mash was sieved on a $2 \mathrm{~mm}$ diameter sieves to obtain native mango purée. Separated rind was also mashed under the same conditions.

\subsection{Cell-Wall Materials}

Mashed mango or rind was suspended in five volumes of hot $95 \%$ (v/v) ethanol. The slurry was washed with $80 \%$ ethanol until the elute responded negatively to anthrone reagent. The raw alcohol-insoluble residue was freeze-dried, ground in a hammer mill and sieved (mesh size $<500 \mu \mathrm{m}$ ). It was then suspended in cold water $\left(4^{\circ} \mathrm{C}\right)$ and washed thoroughly to remove soluble materials. The lost weight corresponded to the total content of water-soluble pectin (WSP). An aliquot of the recovered washing water was dialysed against distilled water, concentrated and freeze-dried to obtain part of the WSP for subsequent analysis.

Starch and cytoplasmic proteins were partially removed, following the methodology presented by Brillouet, et. al.[18] Briefly, nonhydrosoluble residue was incubated with a protease (pronase) derived from Streptomyces griseus (and supplied by Boehringer-Mannheim, Germany), and then with a thermostable a-amy lase (Thermamyl Liquid $60 ®$ from Novo Industrials, Denmark) and an amyloglucosidase from Aspergillus niger (Merck, Germany). The slurry was subsequently deproteinated and destarched, and centrifuged. It was washed thoroughly with distilled water to remove soluble materials and thus, obtain residue that was insoluble in both water and alcohol (WAIR). The WAIR corresponded to purified insoluble, cell-wall polysaccharides was freeze-dried, milled and sieved (mesh size $<500 \mu \mathrm{m}$ ). The AIR corresponded to the sum of total contents of WSP and WAIR.

\subsection{Che mical and Physical Analysis}

Mango purée was analysed for $\mathrm{pH}$, titratable acidity, dry matter, ash, soluble solids, total sugars and reducing sugars, using standard methods[19]. Vitamin C was assessed by the reflectometric method, using an ascorbic acid test (Merck's Reflectoquant $($ kit).

Cellulose and hemicellulose were extracted by selective fractionation of WAIR according to methods as described by Voragen et. al.[20]. Lignin was determined according to Effland.[21] Proteins were estimated, using the Kjeldahl method. Neutral sugars were analysed by gas chromatography (GC) (Shimadzu 14B, detector FID), featuring a Supelco SPB-225 column $(30 \mathrm{~m} \times 0.32 \mathrm{~mm})$, after hydrolysing residues either by the Saeman $\left(\mathrm{H}_{2} \mathrm{SO}_{2}\right.$ $72 \%)$ or the trifluoroacetic acid (2 M) hydrolysis, and conversion of sugars to alditol acetates, according to the method adapted from Brillouet, et. al.[18] and Harris et. a1.[22]. Only the higher content of neutral sugars obtained, whether by Saeman or TFA hydrolysis, were reported. Glucose liberated by TFA hydrolysis was reported as non-cellulosic glucose ( $\mathrm{NC}$ glu), whereas cellulosic glucose was estimated as the difference between the TFA and Saeman hydrolyses.

Total neutral sugars were measured, using the anthrone method[23] and deducing interference of galacturonic acid. Uronide material was determined by the m-hydroxydiphenyl spectrophotometric method.[24] Starch content was determined following the enzymatic procedure described by Batey.[25] Methylation analys is of galacturonic acid was performed as described by Klavons et. al.[26] Suspended insoluble solids (SIS) were assessed as the percentage weight of the residue after centrifuging mango purée at $1000 \mathrm{~g}$ for $15 \mathrm{~min}$. Consistency was assessed with a Bostwick consistometer, using $90 \mathrm{~g}$ of purée at a constant temperature $\left(25 \pm 2^{\circ} \mathrm{C}\right.$ ), and measuring the distance (in $\mathrm{cm}$ ) the pulp flowed under its own weight on a $15^{\circ}$ slope for 30 seconds. Average of three consecutive tests was reported. Mesocarp firmness was assessed with a fruit pressure tester (Gullime ${ }^{\circledR}$ ), featuring a probe with a $0.8-\mathrm{mm}$ diameter. Two measures per fruit were taken at opposite sides after 
removing peel.

\subsection{Enzymatic Activity}

Activity of endo-1-4-ß-D-glucanase (Cx; EC 3.2.1.4), pectin lyase (PL; EC 4.2.2.10) Pectinesterase (PE; EC 3.1.1.11), Endo-polygalacturonase (PG; EC 3.2.1.15) and $\square$-L-arabinofuranosidase (EC 3.2.1.55) were assessed as described elsewhere[27]. The other enzymatic activities $(1,4) \quad-D$-mannanase (EC 3.2.1.78), $(1,4) \quad$-D galactanase (EC 3.2.1.89), and (1,4) -D-xylanase (EC 3.2.1.8) were assessed, using insoluble chromogenic substrates, that is, AZCL-galactomannan, AZCL-galactan and AZCL-xylan (all from Megazyme International Ireland), at 2\% (w/v) in acetate buffer $(25 \mathrm{mM})$ at $\mathrm{pH} 4.5,4.3,4.7$ respectively. Substrate solutions with the enzymatic preparation were incubated at $40{ }^{\circ} \mathrm{C}$ for $10 \mathrm{~min}$. Then, high molecular substrates were removed, emp loying 2.5 volu mes of ethanol at $95 \%(\mathrm{v} / \mathrm{v})$ and centrifuging at $1000 \mathrm{~g}$. In the supernatant, the absorbance at $590 \mathrm{~nm}$ of the released dye-labelled polysaccharide frag ments was measured. En zy matic activity was determined by reference to a standard curve provided by the manufacturer (Megazy me International Ireland).

\subsection{Enzymatic Treatment}

Two commercial enzyme solutions, Rapidase ${ }^{\circledR}$ Carrot Juice and Rapidase ${ }^{\circledR}$ Pomaliq 2F, were purchased from DSM (Seclin, France). En zy matic hydrolys is of WAIR was performed as follows: $10 \mathrm{mg}$ of WAIR was suspended in 10 $\mathrm{ml}$ of phosphate buffer at the $\mathrm{pH}$ of each fruit $(\mathrm{pH} 3.5$ for Tommy Atkins and 4.7 for Kent). The en zy me concentrated between 5 and $50 \mu 1$ per gram of WAIR, was added, and the whole incubated for $90 \mathrm{~min}$ between 30 and $60^{\circ} \mathrm{C}$, and gently agitated. The enzyme was inactivated by heating for $5 \mathrm{~min}$ at $80^{\circ} \mathrm{C}$, and the slurry centrifuged at $6000 \mathrm{~g}$ for $10 \mathrm{~min}$. A blank without enzyme was also implemented. The supernatant was recovered for subsequent analysis of liberated sugars. All enzymatic preparations used were previously assessed for their endogenous content in AGU and in neutral sugars to report only sugars liberated from WAIR. Assays on native mango purées were done by introducing $1 \mathrm{ml}$ of diluted enzy me solution to $100 \mathrm{~g}$ of purée, incubating at $45^{\circ} \mathrm{C}$ with gentle magnetic agitation. Then, purées were pasteurized at $80{ }^{\circ} \mathrm{C}$ during 5 min for subsequent analys is of SIS and Bostwick consistency.

\subsection{Experimental Designs}

Two central composite rotatable designs (CCRD), , both with two variables (X1 and X2) corresponding to (1) temperature and enzyme concentration to assess response pattern of WAIR solubilisation; and (2) time and enzyme concentration to estimates responses on native mango purée. Responses (Y) were computed, using statistical software (JMP, v. 9.02, SAS Institute) to fit a second-order polynomial equation:

$\mathrm{Y}=\mathrm{a} 0+\mathrm{a} 1 \mathrm{X} 1+\mathrm{a} 2 \mathrm{X} 2+\mathrm{a} 11 \mathrm{X} 12+\mathrm{a} 22 \mathrm{X} 22+\mathrm{a} 12 \mathrm{X} 1 \mathrm{X} 2 \quad$ (Eq 2)

Statistical analyses, like coefficient of regression $\mathrm{R}^{2}$, analys is of variance and P-value as sociated were calculated. Variance of experimental error was assessed by repeating experiment at least three times in the centre of the experimental field. A P-value, called $\mathrm{P}_{\text {lof }}$ was also used to test if the variance of residual corresponding to the lack of fit was similar to experimental error. Finally, a plot of residual versus predicted value was analysed to check for randomized pattern. All these analyses were provided by the software JMP (v. 9.02, SAS Institute). Once the model has been validated, response surfaces were presented as contour plot graph using the software Sig maPlot V7, 2001.

\section{Results and Discussion}

\subsection{Gener al Char acterization of Mango Fruits}

At optimal maturity, both varieties Kent and Tommy Atkins differed slightly for several physico-chemical properties. Major differences were found for $\mathrm{pH}$ and acidity, firmness, and soluble solids and vitamin $\mathrm{C}$ contents (Table 1). Kent appears to be sweeter and less acid, and to contain 50\% more vitamin $\mathrm{C}$ than does Tommy Atkins. The pericarp always presented higher vitamin $\mathrm{C}$ content than did mesocarp. The flesh is firmer in Tommy Atkins than for Kent.

Table 1. Main physico-chemical characterist ics of mangoes mesocarp and pericarp

\begin{tabular}{|c|c|c|c|c|c|}
\hline & & $\begin{array}{c}\text { T.Atkins } \\
\text { (mesocarp) }\end{array}$ & $\begin{array}{c}\text { "Kent" } \\
\text { (mesocarp) }\end{array}$ & $\begin{array}{c}\text { T. Atkins } \\
\text { (pericarp) }\end{array}$ & $\begin{array}{c}\text { “Kent” } \\
\text { (pericarp) }\end{array}$ \\
\hline Total solubles solids & ${\mathrm{g} . \mathrm{kg}^{-1}}^{-1}$ & $140 \pm 130$ & $182 \pm 19$ & $60 \pm 6$ & $80 \pm 9$ \\
\hline $\mathrm{pH}$ & & $3.49 \pm 0.1$ & $4.72 \pm 0.01$ & $4.63 \pm 0.00$ & $4.33 \pm 0.00$ \\
\hline Flesh firmness & $\mathrm{kg} . \mathrm{cm}^{-2}$ & $5.7 \pm 1.6$ & $4.7 \pm 1.8$ & - & - \\
\hline Titratable acidity & \% equ. citric acid & $0.43 \pm 0.01$ & $0.12 \pm 0.00$ & $0.46 \pm 0.01$ & $0.75 \pm 0.01$ \\
\hline Dry matter & $\%$ & $17.46 \pm 0.17$ & $21.20 \pm 0.18$ & $20.38 \pm 0.5$ & $24.51 \pm 0.20$ \\
\hline Ash & $\%$ & $0.35 \pm 0.01$ & $0.39 \pm 0.01$ & $0.72 \pm 0.03$ & $0.86 \pm 0.02$ \\
\hline Vitamin C & mg.kg-1 & $230 \pm 11$ & $497 \pm 8$ & $486 \pm 63$ & $630 \pm 17$ \\
\hline Starch & $\%$ & $0.09 \pm 0.006$ & $0.11 \pm 0.006$ & $0.28 \pm 0.06$ & $0.09 \pm 0.06$ \\
\hline Total sugars & $\%$ & $14.07 \pm 1.81$ & $18.69 \pm 0.88$ & $10.93 \pm 0.17$ & $15.11 \pm 0.82$ \\
\hline Red. sugars & $\%$ & $3.07 \pm 0.23$ & $4.87 \pm 0.05$ & $4.58 \pm 0.13$ & $4.92 \pm 0.08$ \\
\hline
\end{tabular}




\subsection{Char acterization of Cell-Wall Polysaccharides}

The AIR, after deproteination and destarching, represented $1.7 \%$ and $1.45 \%$, respectively, of the mesocarp from Tommy Atkins and Kent, and $7.2 \%$ and $4.1 \%$ of the pericarp (Table 2). The value for the mesocarp fro $m$ To mmy Atkins is slightly higher than the $1.1 \%$ found by other authors [10]. However, differences may be explained by the different ext raction method followed. High content of AIR is responsible for the higher firmness of table mangos that are selected as better able to withstand mechanical stresses. The higher content of AIR in Tommy Atkins's flesh explains the higher firmness observed previously. Both varieties yield almost the same amount of flesh (mesocarp). Although Kent has a thicker skin, it is counterbalanced by having a s maller seed that represents only $4 \%$ of the whole fruit, compared with $11 \%$ for Tommy Atkins.

Cellulose is the predominant component of AIR in the mesocarp, being a round $37 \%$ for To mmy Atkins and $45 \%$ for Kent. Cellulose content is lower in the pericarp where soluble pectin is the major component (30\% for Tommy Atkins and $40 \%$ for Kent). In the flesh (mesocarp), soluble pectin (WSP) represents only $32 \%$ of the AIR for Tommy Atkins and $25 \%$ for Kent. The content of hemicellulose is similar for both varieties. The amount of lignin in the Tommy Atkins mesocarp exceeded that in Kent, data, which can be also correlated with greater firmness.

Table 2. Main component of alcohol-insoluble-residue (AIR) (Results expressed as mass fractions $\mathrm{g}^{\mathrm{kg}} \mathrm{g}^{-1} \mathrm{SE} \mathrm{n}=3$ )

\begin{tabular}{|c|c|c|c|c|c|c|c|c|c|c|c|c|}
\hline & & \multirow{3}{*}{$\begin{array}{l}\% \text { of } \\
\text { fruit }\end{array}$} & \multirow{3}{*}{$\mathrm{AIR}^{\mathrm{a}}$} & \multicolumn{9}{|c|}{ In $\mathrm{AIR}^{\mathrm{b}}$} \\
\hline & & & & \multirow{2}{*}{ WSP } & \multicolumn{7}{|c|}{ WAIR } & \multirow[b]{2}{*}{ Total } \\
\hline & & & & & Uronides $^{c}$ & Cellulose & Hemi-cellulose & Lignin & Protein & $\begin{array}{c}\text { Residual } \\
\text { starch }\end{array}$ & Ash & \\
\hline \multirow{2}{*}{ 迆 } & Mesocarp & $79 \pm 3$ & $17 \pm 1$ & $320 \pm 22$ & $93 \pm 3$ & $374 \pm 21$ & $45 \pm 3$ & $46 \pm 3$ & $25 \pm 3$ & $41 \pm 3$ & $9 \pm 1$ & 953 \\
\hline & Pericarp & $10 \pm 1$ & $72 \pm 3$ & $400 \pm 31$ & $116 \pm 7$ & $200 \pm 11$ & $14 \pm 1$ & $74 \pm 3$ & $37 \pm 3$ & $34 \pm 3$ & $14 \pm 1$ & 889 \\
\hline \multirow{2}{*}{ 苞 } & Mesocarp & $77 \pm 5$ & $14 \pm 1$ & $250 \pm 15$ & $85 \pm 5$ & $455 \pm 25$ & $59 \pm 3$ & $24 \pm 1$ & $53 \pm 4$ & $57 \pm 5$ & $13 \pm 1$ & 996 \\
\hline & Pericarp & $19 \pm 2$ & $41 \pm 2$ & $300 \pm 21$ & $116 \pm 9$ & $249 \pm 9$ & $16 \pm 1$ & $96 \pm 5$ & $35 \pm 4$ & $48 \pm 5$ & $25 \pm 1$ & 885 \\
\hline
\end{tabular}

a $\mathrm{g} \cdot \mathrm{kg}^{-1}$ in fresh matter

g. kg in dry AIR

${ }^{\mathrm{c}}$ including methanol

Table 3. Sugar composition of purified mango cell-walls (WAIR) in the different fract ions (SE $n=4)$

\begin{tabular}{|c|c|c|c|c|c|c|c|c|c|c|}
\hline & & Rha $^{\text {a }}$ & Fuc $^{a}$ & $\operatorname{Ara}^{a}$ & $\mathrm{Xyl}^{\mathrm{a}}$ & $\operatorname{Man}^{a}$ & $\mathrm{Gal}^{\mathrm{a}}$ & $\mathrm{Glu}^{\mathrm{b}}$ & Glu. $\mathrm{NC}^{\mathrm{c}}$ & $\begin{array}{l}\text { Uronides } \\
\left(\mathrm{DE}^{\mathrm{d}}\right)\end{array}$ \\
\hline & & \multicolumn{9}{|c|}{$\%$ mol of hydrosoluble pect in fraction (WSP) } \\
\hline \multirow{2}{*}{ 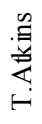 } & Mesocarp & 1.2 & 0.9 & 11.3 & 6.2 & 1.1 & 5.8 & - & 12.3 & $61.2(78 \%)$ \\
\hline & Pericarp & 2.2 & 0.2 & 21.0 & 1.0 & 0.5 & 31.3 & - & 0.8 & $43(87 \%)$ \\
\hline \multirow{2}{*}{$\begin{array}{l}\hat{\vec{D}} \\
\underline{0}\end{array}$} & Mesocarp & 1.1 & 0.7 & 6.3 & 5.1 & 1.3 & 4.7 & - & 5.7 & $75.1(62 \%)$ \\
\hline & Pericarp & 1.8 & 0.3 & 9.8 & 1.8 & 1.0 & 30.8 & - & 4.3 & $50.2(79 \%)$ \\
\hline & & \multicolumn{9}{|c|}{$\begin{array}{l}\% \text { mol of residue insoluble in water and alcohol } \\
\qquad(\% \text { w/wof WAIR })\end{array}$} \\
\hline \multirow{2}{*}{ 兽 } & Mesocarp & $\begin{array}{l}0.8 \\
(0.4)\end{array}$ & $\begin{array}{l}2.1 \\
(1.1)\end{array}$ & $\begin{array}{c}6.2 \\
(3.0)\end{array}$ & $\begin{array}{l}12.5 \\
(6.1)\end{array}$ & $\begin{array}{l}4.1 \\
(2.4)\end{array}$ & $\begin{array}{l}5.6 \\
(3.3)\end{array}$ & $\begin{array}{l}42.2 \\
(24.6)\end{array}$ & $\begin{array}{l}6.7 \\
(3.9)\end{array}$ & $\begin{array}{c}19.8 \\
(12.5)\end{array}$ \\
\hline & Pericarp & 1.8 & 1.4 & 13.6 & 6.5 & 2.9 & 6.5 & 25.5 & 5.2 & 36.6 \\
\hline \multirow{2}{*}{ 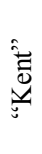 } & Mesocarp & $\begin{array}{l}0.4 \\
(0.2)\end{array}$ & $\begin{array}{c}2.4 \\
(1.3)\end{array}$ & $\begin{array}{l}3.1 \\
(1.6)\end{array}$ & $\begin{array}{l}14.0 \\
(6.8)\end{array}$ & $\begin{array}{l}4.3 \\
(2.6)\end{array}$ & $\begin{array}{l}5.9 \\
(3.5)\end{array}$ & $\begin{array}{l}48.6 \\
(28.1)\end{array}$ & $\begin{array}{c}9.9 \\
(5.8)\end{array}$ & $\begin{array}{l}11.4 \\
(7.3)\end{array}$ \\
\hline & Pericarp & 1.5 & 1.5 & 10.8 & 7.0 & 5.0 & 6.8 & 31.1 & 5.0 & 31.2 \\
\hline
\end{tabular}

${ }^{\mathrm{a}}$ Only highest values obtained from both Saeman and TFA hydrolyse was reported

${ }^{\mathrm{b}}$ Cellulosic glucose (Glu) was obtained by differences between hydrolyse with $\mathrm{H}_{2} \mathrm{SO}_{4}$ and TFA

${ }^{c}$ Non cellulosic glucose was given by hydrolysis with TFA

${ }^{\mathrm{d}} \mathrm{DE}$ : Degree of esteri fication 
Results of the complete analysis of sugars in the hydrosoluble pectin (WSP) and in the insoluble cell walls (WAIR) are presented in Table 3. Galacturonic acid is the predominant sugar in WSP ranging from $40 \%$ (pericarp from Tommy Atkins) to almost 74\% (mesocarp from Kent). Soluble pectin was highly esterified, being about $78 \%$ for the mesocarp of both varieties. Highly esterified pectin appears to be a characteristic of mango fruits in concordance with results obtained by[11, 28]. Predominant neutral sugars in the WSP are arabinose, non-cellulosic glucose, xylose and galactose in the mesocarp, showing a probable predominance of arabino-glucans, arabino-xylan or arabino-galactan polysaccharids in the side chains of the soluble pectins. These results are in agreement with those find by other authors who studied more deeply the linkages between neutral sugars[29]. In the soluble pectin from the pericarp, the contents of galactose and arabinose are much higher indicating predominance of arabino-galactan-type polysaccharides. It can be also noted that soluble pectin (WSP) from Kent variety has a higher content of uronids that for Tommy Atkins.

Analysis of sugars in the WAIR shows that glucose proceeding fro m cellulose was the prevailing sugar, followed by uronides and xylose. Predominance of xylose among non-cellulosic neutral sugars has been reported previously for ripe Tommy Atkins[10] and other mango varieties [13]'[28]. The particularly high content of xylose in the WAIR from the mesocarp shows a presumable predominance of xylan-type polysaccharides in the hemicellulosic fraction. In the pericarp, the predominant non-cellulosic neutral sugar is arabinose, followed by xylose and galactose.

\subsection{Selecting an Enzymatic Preparation}

The importance of cellulose and insoluble pectin in mango cell walls implies the need to use an enzymatic preparation able to hydrolyze at least both substrates. Nonetheless, the importance of other sugar polymers also may imply the use of other side enzymes, specifically, xy lanases and arabinases. Seven commercial preparations were tested (data not shown), and among them, Rapidase ${ }^{\circledR}$ Carrot Juice and Rapidase ${ }^{\circledR}$ Pomaliq were able to solubilize the highest amount of insoluble cell walls from mango mesocarp (WAIR). The main spectrum of enzymatic activities of both commercial preparations has been published previously[18, 27]. They contain a high and balance amount of pectinases and cellulases, as well as other side activities, contrary to the other preparation tested (data not shown). The central composite rotatable design implemented, allowed testing different temperatures and enzyme concentrations, ranging respectively from 30 to $60^{\circ} \mathrm{C}$ and from the equivalent of 50 to $500 \mu \mathrm{l}$ per liter of mango purée (the mango purée being studied contains $10 \pm 0.015 \mathrm{~g}$ ofWAIR per kilogram of purée, as calculated from Table 2 for both varieties). The second-degree models obtained after computing the results of the experimental design gave rise to excellent statistical test values $\left(r^{2}>0.95 ; \mathrm{P} \leq 0,01 ; \mathrm{P}_{\text {lof }}>10 \%\right)$. Corresponding response surfaces are presented as contour plot graphs in Fig. 1 and 2 .

Figure 1 shows, that for both preparations, at an equivalent of $500 \mu 1$ per kilogram of purée, $100 \%$ of uronides (AGU) is released in the same way for both varieties as values around $12 \% \mathrm{w} / \mathrm{w}$ of WAIR are inclusively slightly higher than the ones obtained by chemical hydrolysis (Table 2). Figure 1 also shows that no significant differences between both preparations were found for the rate at which uronic material was released. The similar activity of the pectin lyase in both preparations may explain this result, as mango pectin is highly esterified. In fact, higher polygalacturonase and pectinesterase activities in Rapidase ${ }^{\circledR}$ Carrot Juice preparation[27] did not seem to improve uronides release. Figure 1 shows also that optimum temperature for pectinase activity is between 45 and $50^{\circ} \mathrm{C}$.
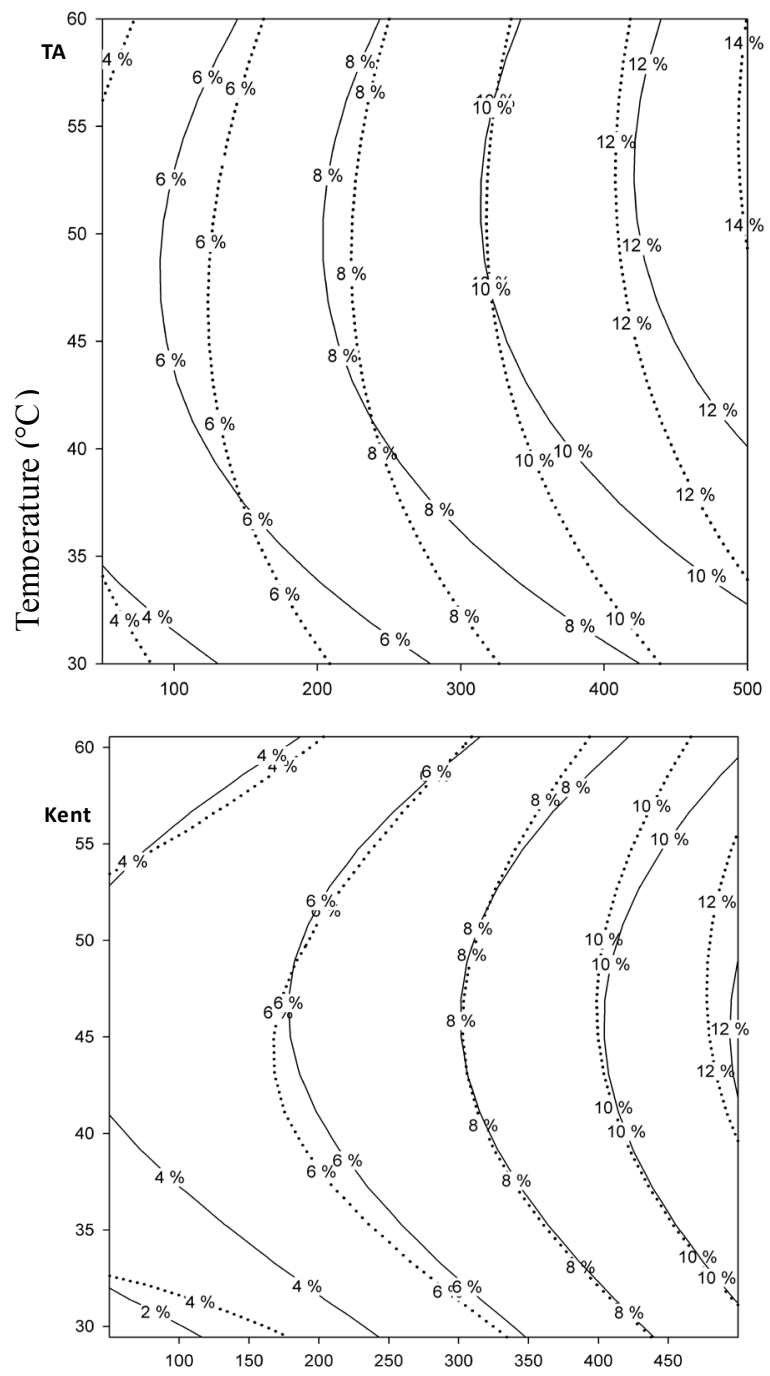

Enzyme concentration $\mu 1 . \mathrm{kg}^{-1}$ of mango puree

Figure 1. Solubilisation of galacturonic acid (as \% of WAIR) obtained after $90 \mathrm{~min}$ incubation, respectively on mango mesocarp from Tommy Atkins (ТА $(\mathrm{pH} 4.7)$ and "Kent” (Kant) $(\mathrm{pH} 3.5)$ by Rapidase Pomaliq (---) and Rapidase carrot ${ }^{\circledR}(--)$ 

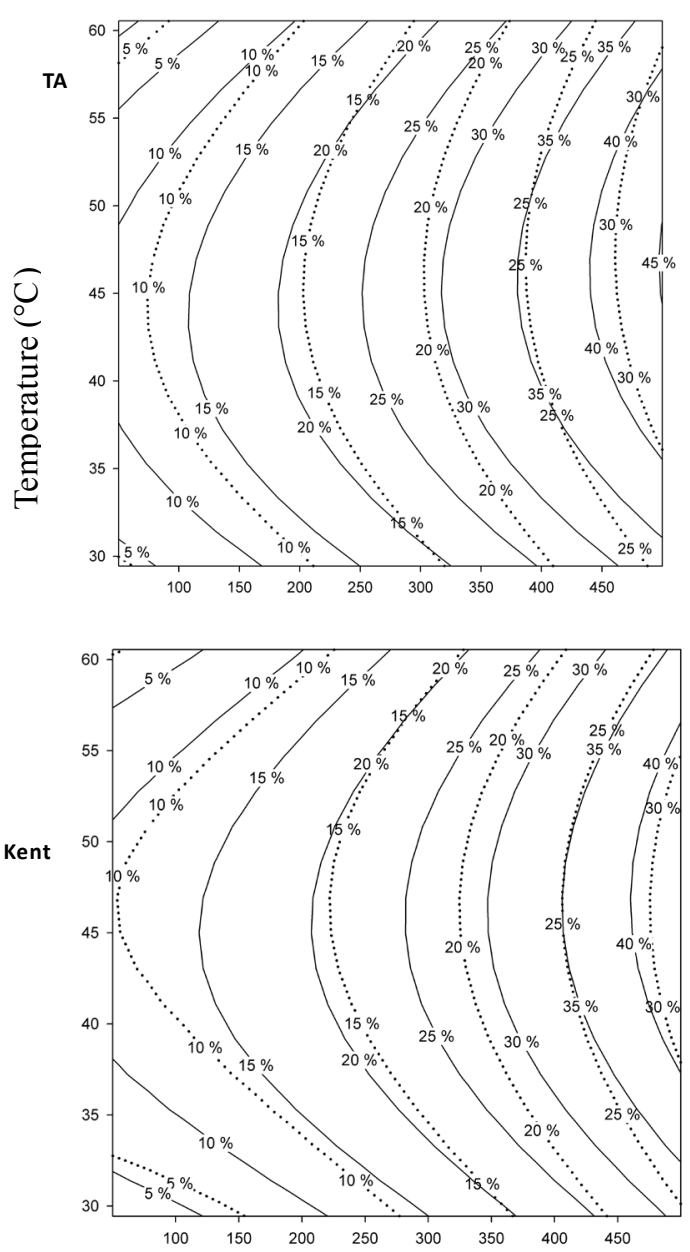

Enzyme concentration $\mu 1 . \mathrm{kg}^{-1}$ of mango puree

Figure 2. Solubilisation of neutral sugars (as \% of WAIR) obtained after $90 \mathrm{~min}$ incubation, respectively on mango mesocarp from Tommy Atkins $(\mathrm{TA})(\mathrm{pH} 4.7)$ and "Kent" (Kent) (3.5) by Rapidase Pomaliq ${ }^{\circledR}(----)$ and Rapidase carrot ${ }^{\circledR}(--)$

For both varieties, Rapidase ${ }^{\circledR}$ Pomaliq appears to be more efficient in releasing neutral sugars (Fig. 2) than the other enzymatic preparation at the same concentration. In fact, taking into account total neutral sugars content in WAIR endocarp (Table 3), Rapidase ${ }^{\circledR}$ Po maliq is able to release up to $90 \% \mathrm{w} / \mathrm{w}$ of neutral sugars contained in WAIR fro $\mathrm{m}$ both varieties, whereas Rapidase Carrot Juice ${ }^{\circledR}$ releases less than
$70 \%$ at $45^{\circ} \mathrm{C}$ and at a concentration level equivalent to $500 \mu \mathrm{l}$ per kilogram of mango purée.

Even so, both preparations appear to have had very similar content of cellulase enzymes, differing only slightly for the ratio endoglucanase to cellobiohydrolase (1.9 for Rap idase ${ }^{\circledR}$ Pomaliq and 1.5 for Rapidase ${ }^{\circledR}$ Carrot Juice) and for xy lanase and exo arabinase (table 4). A higher exo-arab inase activity in Rapidase ${ }^{\circledR}$ Carrot Juice does not seem to make a difference, probably because this enzyme acts mainly on the side chain of the previously solubilised pectin. In contrast, higher xylanase activity appears to be a factor that may explain the better solubilization rate observed, as xylose prevails in the noncellu losic fraction of neutral sugar from WAIR mesocarp. Neutral sugars from Kent's WAIR, appear to be more easily released than for Tommy Atkins. A higher content of cellulose in Kent, less lignin content and a natural $\mathrm{pH}$ closer to the optimal $\mathrm{pH}$ of endocellulase[30] may explain this result.

\subsection{Obtaining Mango Purées of Given Bostwick Consistencies}

Native mango purées obtained immediately after sieving are extremely rich in insoluble suspended solids (SIS; $84 \%$ for Tommy Atkins and $73 \%$ for Kent), giving rise to low Bostwick consistency ( 8 and $12 \mathrm{~cm} .30 \mathrm{~s}^{-1}$ respectively for Tommy Atkins and Kent) (Table 5, run 1) only comparable to concentrated banana purée[17]. Purée from Kent variety appears to be less consistent than Tommy Atkins which is in agreement with previous results.

As it can be observed in Fig. 3, enzy mat ic treatment with Rapidase ${ }^{\circledR}$ Pomaliq significantly decreases SIS and Bostwick consistency. By using relatively low concentrations of enzymes (150 ml per kilogram of purée) for $60 \mathrm{~min}$ of incubation, we could reduce SIS content by almost $30 \%$ and increase flow velocity on the Bostwick consistometer by approximately the same amount in both purées. For a very similar result on SIS, other authors[14] used much more enzyme solution (up to $2 \mathrm{ml} \mathrm{kg}{ }^{-1}$ ), containing mainly pectinesterase and polygalacturonase activities.

Table 4. Characterization of activities (nKat. $\mathrm{ml}^{-1}$ ) of two of the commercial preparation used

\begin{tabular}{|c|c|c|c|}
\hline & Activity & Rap. carrot & Rap. pomaliq $^{\text {a }}$ \\
\hline \multirow{4}{*}{ Pectinases } & Pectin lyase & $834 \pm 100$ & $1100 \pm 150$ \\
\cline { 2 - 4 } & Polygalacturonase & $4330 \pm 500$ & $750 \pm 100$ \\
\cline { 2 - 4 } & Pectin-methyl esterase & $29100 \pm 3000$ & $8770 \pm 1000$ \\
\hline \multirow{3}{*}{ Cellulases } & Endoglucanase & $3420 \pm 300$ & $3300 \pm 400$ \\
\cline { 2 - 4 } & Cellobiohydrolase & $5120 \pm 500$ & $6370 \pm 700$ \\
\hline \multirow{3}{*}{$\begin{array}{c}\text { Segondary } \\
\text { activities }\end{array}$} & Xylanase & $1384 \pm 150$ & $6501 \pm 600$ \\
\cline { 2 - 4 } & Mannanase & $500 \pm 50$ & $800+100$ \\
\cline { 2 - 4 } & Galactanase & $730 \pm 100$ & $780+100$ \\
\hline
\end{tabular}


Table 5. Responses applying the CCRD for enzymatic liquefaction of cherimoya purée varying enzyme concentration and incubation time (temperat ure $\left.45^{\circ} \mathrm{C}\right)$

\begin{tabular}{|c|c|c|c|c|c|c|}
\hline Run & $\begin{array}{l}\text { Concentration } \\
\left(\mu l . \mathrm{kg}^{-1}\right)\end{array}$ & $\begin{array}{l}\text { Time } \\
(\mathrm{min})\end{array}$ & $\begin{array}{l}\text { SIS T A } \\
(\%)^{\mathrm{a}}\end{array}$ & $\begin{array}{l}\text { SIS Kent } \\
(\%)^{\mathrm{a}}\end{array}$ & $\begin{array}{l}\text { Consistency TA } \\
\left(\mathrm{cm} \cdot 30 \mathrm{~s}^{-1}\right)^{\mathrm{a}}\end{array}$ & $\begin{array}{l}\text { Consistency Kent } \\
\left(\mathrm{cm} \cdot 30 \mathrm{~s}^{-1}\right)^{\mathrm{a}}\end{array}$ \\
\hline 1 & 0 & 35 & 83.8 & 73.6 & 8.0 & 12.0 \\
\hline 2 & 30 & 10 & 78.4 & 69.6 & 8.5 & 12.0 \\
\hline 3 & 30 & 60 & 57.6 & 59.3 & 9.0 & 13.0 \\
\hline 4 & 90 & 0 & 78.7 & 71.7 & 8.0 & 12.0 \\
\hline 5 & 90 & 35 & $56.9 \pm 1$ & $58.2 \pm 1$ & $9.0 \pm 0.5$ & $13.0 \pm 1$ \\
\hline 6 & 90 & 70 & 54.0 & 53.2 & 9.5 & 15.0 \\
\hline 7 & 150 & 10 & 72.6 & 62.0 & 8.5 & 13.0 \\
\hline 8 & 150 & 60 & 53.8 & 52.0 & 10.5 & 15.5 \\
\hline 9 & 175 & 35 & 55.7 & 49.7 & 9.5 & 14.5 \\
\hline
\end{tabular}

${ }^{a}$ Average of three consecutive tests

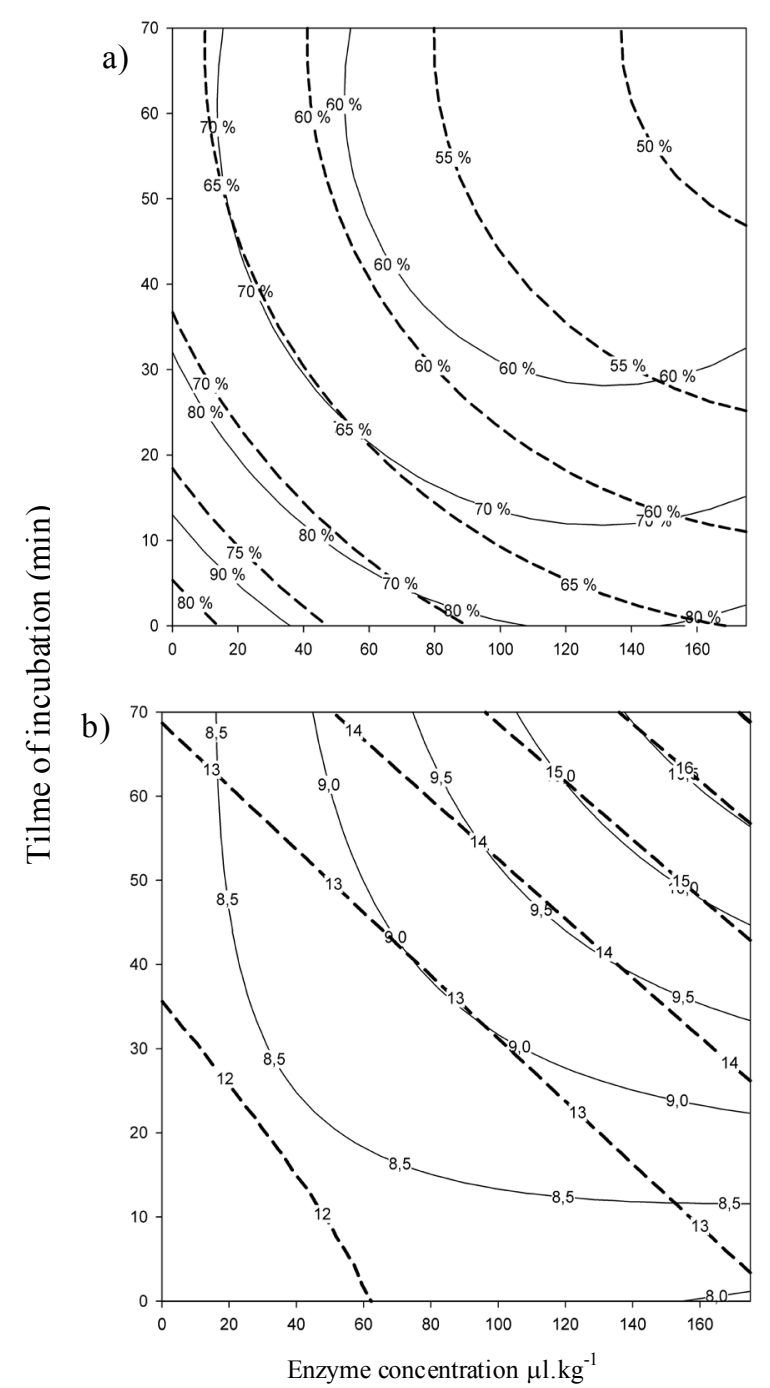

Figure 3. Contour plot of responses on mango puree from "Tommy Atkins" (----) and "Kent" (-) after incubation at $45{ }^{\circ} \mathrm{C}$ with Rapidase Pomaliq $\left(\right.$ : a) \% SIS; b) consistency $\left(\mathrm{cm} . \mathrm{min}^{-1}\right)$

Additionally, by modulating incubation time and enzyme concentration, we could obtain purées with different Bos twick consistency. SIS content and Bostwick cons istency can be predicted by using mathematical models obtained through computing CCRD results (table 5). Mathematical models fit well, as $r^{2}$ was always superior to 0,92 and $\mathrm{P} \leq 0,01$, $\mathrm{P}_{\text {lop }}>10 \%$. We can see, in concordance with previous results, that Tommy Atkins purée appears to be less easily liquefied than Kent. Even so, we could obtain from both varieties mango purée that was consistent enough for juices blends, smoothies or baby foods.

\section{Conclusions}

Mango table varieties are characterized by their firmness to endure mechanical stress during handling and transport of fresh fruits. Actually, their higher content of insoluble and soluble pectin, cellulose and xylan-type polysaccharides strengthens the structure of cell-walls, mainly in the flesh. As a consequence, purée resulting from fruits discarded by the export market was generally not considered suitable for the fruit juice industry. Nonetheless, we have shown that the appropriate choice of an en zy matic preparation can change this perspective. We have shown that the application of pectinases and cellulases is not enough and presence of xylanase, which is considered generally as a secondary activity in commercial preparation, was crucial to increase significantly the release of neutral sugars from isolated cell-walls from mango mesocarp. Xylanase may act on xylan-type polysaccharides but the effect on cell-wall solubilization is probably indirect, by facilitating access of pectinases and cellulases to their substrate. As a result, a commercial enzyme that presents high pectinase, cellulase and xylanase activities can reduce drastically content of suspended insoluble solids yielding in minutes a purée with rheological characteristics that can be modulated to fit better the needs of food industries. Additionally, the content of soluble and insoluble fibber of these purées could be high with subsequent health benefits for consumers. Therefore, although, purées of table mango varieties may be less flavorful than purées from other mango varieties, fresh table mangoes discarded from the export market only for visual defects, should be considered as highly valuable raw material for being used by food industries as a basis for 
different juice blends and smoothies with increasing market world wide.

\section{ACKNOWLEDGMENTS}

This study was carried out with financial support from PROMSA-MA G (Contract IQ-CV-077 with INIAP, Quito, Ecuador). The authors wish to thank S. Espin, M. Rodríguez, I. Samaniego, and M. Jaramillo for their valuable help and excellent technical as sistance.

\section{REFERENCES}

[1] FAO, Medium-term prospects for agricultural commodities. In FAO Corporate document repository, Department, E. a. S. D., Ed. 2010.

[2] Yimyong, S.; Datsenka, T. U.; Handa, A. K.; Seraypheap, K. Hot Water Treatment Delays Ripening-associated Metabolic Shift in 'Okrong' Mango Fruit during Storage. J. Am. Soc. Hortic. Sci. 2011, 136 (6), 441-451.

[3] Sreenath, H. K.; Sudarshana-krishna, K. R.; Santhanam, K., Enzymatic liquefaction of some varieties of mango pulp. Lebensmittel-Wissenschaft und Technologie 1995, 28, 196200.

[4] Srivastava, J. S., Mango processing industries- a scenario. Indian Food Packer 1998, Nov-Dec, 43-51.

[5] Gourge, C. M. P.; Champ, M. M. J.; Lozano, Y.; Delfort-Laval, J., Dietary fibre from mango by-products: characterization and hypoglicemic effects determined by in vitro methods. Journal of Agricultural and Food Chemistry 1992, 40, 1864-1868.

[6] Vergara-Valen cia, N.; Granados-Perez, E.; A gama-Acevedo, E.; Tovar, J.; Ruales, J.; Bello-Perez, L. A., Fibre concentrate from mango fruit: Characterization, associated antioxidant capacity and application as a bakery product ingredient. Lwt-Food Sci Technol 2007, 40 (4), 722-729.

[7] Yashoda, H. M.; Prabha, T. N.; Tharanathan, R. N., Mango ripening-chemical and structural characterization of pectic and hemicellulosic polysaccharides. Carbohyd Res 2005, 340 (7), 1335-1342.

[8] Yashoda, H. M.; Prabha, T. N.; Tharanathan, R. N., Mango ripening: changes in cell wall constituents in relation to textural softening. J Sci Food A gr 2006, 86 (5), 713-721.

[9] Muda, P.; Seymour, G. B.; Errington, N.; Tucker, G. A., Compositional changes in cell wall polymers during mango fruit ripening. Carbohyd Polym 1995, 26 (4), 255-260.

[10] Mitcham, E.; McDonald, R., Cell wall modification during ripening of "Keitt" and " Tommy Atkins" man go fruit. Journal of the American Society for Horticultural Science. 1992, 117 (6), 919-924.

[11] Kratchanova; M; Benemou; C; Kratchanov; C, G., On the pectic substances of mango fruits. Elsevier: Kidlington, ROYAUME-UNI, 1991; Vol. 15.

[12] Chauhan, S.; Tyagy, S.; Singh, D., Pectinolytic liquefaction of apricot, plum and mango pulps for juice extraction. International Journal of Food Properties 2001, 4 (1), 103-109.

[13] Olle, D.; Baron, A.; Lozano, Y.; Brillouet, J., Enzymatic degradation of cell wall polysaccharides from mango (M angifera indica L.) puree. Journal of Agricultural and Food Chemistry 2000, 48, 2713-2716.

[14] Rastogi, N. K.; Rashimi, K. R., Optimisation of enzymatic liquefaction of mango pulp by response surface methodology. Eur Food Res Technol 1999, 209 (1), 57-62.

[15] Yashoda, H. M.; Prabha, T. N.; Tharanathan, R. N., Mango ripening - Role of carbohydrases in tissue softening. Food Chem. 2007, 102 (3), 691-698.

[16] Singh, N. I.; Dhuique-Mayer, C.; Lozano, Y., Physico-chemical changes during enzymatic liquefaction of mango pulp (cv. Keitt). J. Food Process Preserv. 2000, 24 (1), 73-85.

[17] Perona, P., Bostwick degree and rherological Properties: An up-to-date viewpoint. Apllied rheology 2005, 15, 218-229.

[18] Brillouet, J. M.; Rouau, X.; Hoebler, C.; Barry, J. L.; Carre, B.; Lorta, E., A new method for determination of insoluble cell walls and soluble nonstarchy polysaccharides from plant materials. Journal of Agricultural and Food Chemistry 1988, 36, 969-979.

[19] AOAC, Fruits and fruit products. In Official Methods of Analysis of the Association of Official Analytical Chemists, Helrich, K., Ed. Association of Official Analytical Chemists: Arlington, USA, 2005; Vol. 2.

[20] Voragen, A. G. J.; Timmers, J. P. J.; Linssen, J. P. H.; Schols, H. A.; Pilnik, W., Methods of analysis for cell wall polysaccharides of fruits and vegetables. Zeitschrift Fur Lebensmittel-Untersuchung Und-Forschung 1983, 177, 251-256.

[21] Effland, M. J., Modified procedure to determine acid-insoluble lignin in wood and pulp. Tappi 1977, 60, 143-144.

[22] Harris, P. J.; Henry, R. J.; Blakeney, A. B.; Stone, B. A., An improved procedure for the methylation analysis of oligosaccharides and polysaccharides. Carbohyd Res 1984, $127,59-73$

[23] Dubois, M.; Gilles, K. A.; Hamilton, J. K.; Robers, P. A.; Smith, F., Colorimetric method for sugars and related substances. Analytical Chemistry 1956, 28 (3), 350-356.

[24] Blumenkrantz, N.; Asboe-Hansen, G., New method for quantitative determination of uronic acids. Analitical Biochemistry 1973, 54, 484-489.

[25] Batey, I. L., Starch analysis using thermostable a-amylase. Starch 1982, 34, 125-128.

[26] Klavons, J. A.; Bennet, R. D., Determination of methanol using alcohol oxydase and its application to methyl ester content of pectins. Journal of Agricultural and Food Chemistry 1986, 34, 597-599.

[27] Brito, B.; Rodriguez, M.; Samaniego, I.; Jaramillo, M. I.; Vaillant, F., Characterising polysaccharides in cherimoya (Annona cherimola Mill.) puree and their enzymatic liquefaction. Eur Food Res Technol 2008, 226 (3), 355-361.

[28] Olle, D.; Lozano, Y.; Brillouet, J., Isolation and 
characterization of soluble poly saccharides and insoluble cell wall material of the pulp of four mango (Mangifera indica L.). Journal of Agricultural and Food Chemistry 1996, 44, $2658-2662$

[29] Prasanna, V.; Prabha, T. N.; Tharanathan, R. N., Pectic polysaccharides of mango (Mangifera indica L): structural studies. J Sci Food Agr 2004, 84 (13), 1731-1735.
[30] Vaillant, F.; Millan, A.; Millan, P.; Dornier, M.; Decloux, M.; Reynes, M., Co-immobilized pectinly ase and endocellulase on chitin and nylon supports. Process Biochemistry 2000,35, 989-996. 